The Brock Review Volume 11 No. 2 (2011)

(C) Brock University

\title{
Strata and Sediment Under the Fog: Geological Landscapes in Smithson and Ewen
} Considered Through Deleuze and Kant

Jakub Zdebik

\begin{abstract}
Strata and Sediment under the Fog focuses on geological landscapes and how they are a standin for the mind's landscape. This article looks at how American artist Robert Smithson describes the mind through geological landscapes in his writings and how Canadian artist Paterson Ewen diagrammatically represents the organization of rocks. The work of these two artists is considered according to the philosophies of Gilles Deleuze and Immanuel Kant-two philosophers who rely on geological and geographical models and metaphors to communicate the function of thought.
\end{abstract}

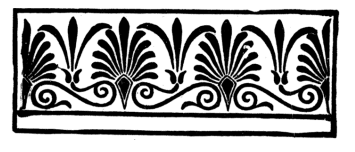

Robert Smithson's drawings of grand scale Earth-works and Paterson Ewen's paintings of colossal earthly phenomena consider the landscape from a geological perspective. In Smithson's art, geology is a stand-in for the topography of the mind. Ewen, for his part, sees in geological structures a matrix of organizational processes. Both artists create geological landscapes to communicate a spatial image of the mind which brings their artistic endeavours on to the plane of a particular philosophical programme. When philosophers attempt to sketch out the landscape of the mind, they resort to a rhetorical constellation associated with geography and, more precisely for the purpose at hand, geology, in order to communicate a spatial image of thought. Geology allows both artists and philosophers to produce an illustration of thought that puts the emphasis on the notion of organization.

Philosophers Gilles Deleuze and Immanuel Kant often describe imaginary aesthetic landscapes in their writings. Their rhetorical images are helpful to uncover the chthonic vistas explored by Smithson and Ewen because the philosophers use geological landscapes to represent their respective philosophical systems. Much like the aforementioned artists, Deleuze and Kant enlist geological elements such as volcanoes, islands, strata and sediments, mapped out on the terrain of the earth and stretched out in the geological time of millions of years, in order to transmit an image of thought. 


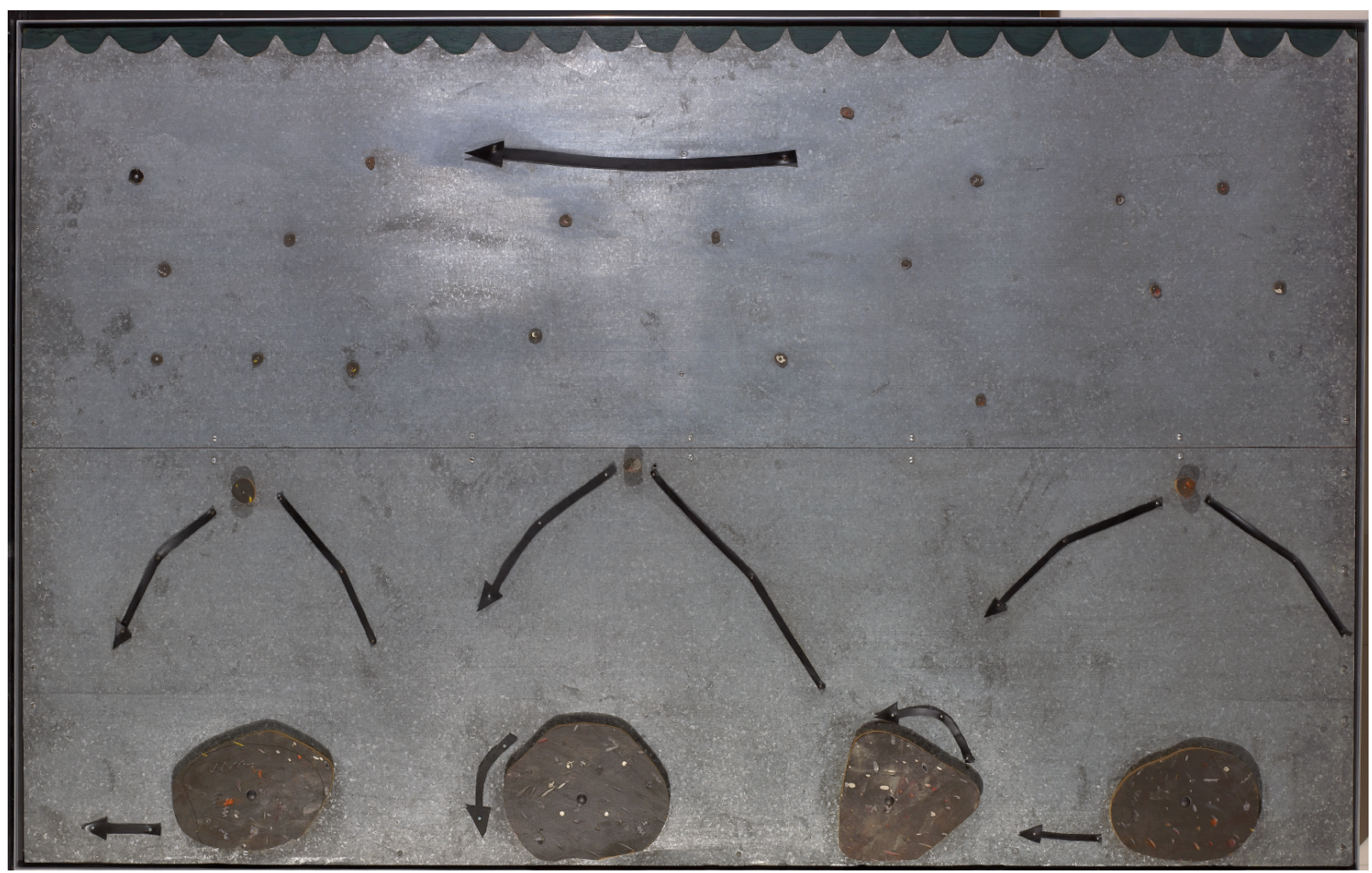

Paterson Ewen, Rocks Moving in the Current of a Stream, (1971).

Steel screws and bolts, rubber, linoleum, plywood, acrylic paint, galvanized steel $153.3 \mathrm{~cm}$ x $245.3 \mathrm{~cm}$.

With Permission from the Estate of Paterson Ewen and Art Gallery of Ontario

In what follows, I will juxtapose Smithson's Island Project, 1970 with Deleuze's concept of stratification to compare their treatment of thought through geological images. In addition, I will show Kant's metaphorical use of geography, which schematically reflects the empirical element in his philosophy, in advance of Ewen's Rocks Moving in the Current of a Stream, 1971. Scientific notation stemming from geology pushed Ewen's interest in exploring the communicability of scientific data through the representation of natural phenomena, much like Smithson's leading concept of entropy shapes his interest in mental landscapes. The artists' works and philosophers' use of rhetorical images illustrate geological mechanisms that relate to the organization of the environment, society and, by extension, the network of an intellectual community. In the final section of my essay, I will synthesize the consequences of Smithson's geology, Deleuze's strata, Kant's cartographic metaphors and Ewen's diagrammatic art through Manuel DeLanda's organizational models of matter, environment and society in order to show the importance of the geological landscapes created by 
artists for the representation of an intangible, processual reality in which materiality and thought are dynamically interwoven.

\section{Smithson and Entropy}

The thermodynamic principle of entropy - the loss and degradation of energy and matter in all things-is at work in many of Smithson's Earth-Art pieces, which are left at the mercy of the elements. Site-specific works such as Partially Buried Woodshed, 1970 and Spiral Jetty, 1970 come to mind as artworks that were overtaken by the environment, some more permanently than others. As Craig Owens explains in his essay on allegory and postmodernism, this breakdown of the work of art by nature is an integral part of the artistic process of Smithson's work:

Site-specific works are impermanent, installed in particular locations for a limited duration, their impermanence providing the measure of their circumstantiality. Yet they are rarely dismantled but simply abandoned to nature; Smithson consistently acknowledged as part of his works the forces which erode and eventually reclaim them for nature. ${ }^{1}$

Yet, as important as entropy is for the aesthetic degradation of the work of art, it is also a crucial component that animates the shifting of the mind's terrain. Smithson describes his concept of "abstract geology," the artistic depiction of a geography of the mind, as follows:

One's mind and the earth are in a constant state of erosion, mental rivers wear away abstract banks, brain waves undermine cliffs of thought, ideas decompose into stones of unknowing, and conceptual crystallizations break apart into deposits of gritty reason. Vast moving faculties occur in this geological miasma, and they move in the most physical way. This movement seems motionless, yet it crushes the landscape of logic under glacial reveries. This slow flowage makes one conscious of the turbidity of thinking. Slump, debris slides, avalanches all take place within the cracking limits of the brain. ${ }^{2}$

It is from this interconnection between mind and earth, between a geological and spatial representation of the mind that the body as a marker of time arises. As Smithson announces, the spatial representation of the mind comes into contact with a geography that is layered and dynamic. Smithson compares the mind to the earth as affected by erosion, but the effect of the sentence produces a strange coupling between geography and thought: it is a material and abstract chimerical landscape that exists in words, in the text. The text, or the rhetorical image described in the text, seems to mediate between thought and the art object. Smithson's slow-moving mental terrain, it 
must be noted, is itself connected with the exteriority of the body, which constitutes a bridge of sorts between mind and landscape:

The entire body is pulled into the cerebral sediment, where particles and fragments make themselves known as solid consciousness. A bleached and fractured world surrounds the artist. To organize this mess of corrosion into patterns, grids, and subdivisions is an esthetic process that has scarcely been touched. ${ }^{3}$

First, the body, in which this landscape is produced, is dragged back into the landscape's sedimentary crust in a paradoxical move seemingly patterned on the Moebius Strip. The figure standing in the middle of this landscape, then, is that of the artist. Finally, the third sentence of the passage declares the mission of the artist: to organize into patterns and grids - into a new kind of aesthetic style - the pluralistic, unstable and fractured landscape that surrounds the artist. As we will soon see, this is the aesthetic organization and schematic representation that Ewen shares with Smithson. For Smithson, however, the challenge of capturing entropy in art objects narrows the focus of his oeuvre.

Island Project, 1970 and Entropic Island, 1970 illustrate the geological landscapes Smithson describes in "Sedimentation of the Mind". These drawings stage dystopian landscapes where building materials and architectural structures are falling apart or are buried by dirt and rocks. Entropic Island is particularly systematic in cataloguing Smithson's works and themes. Robert Hobbs compares the aesthetics of these drawings to Giovanni Battista Piranesi's etchings, especially his Carceri etchings of 1745, which have a baroque flair for the dramatic, haunting and fantastical aggregate of subterranean architectural elements: "Smithson was fascinated by Piranesi's visionary evocations of Roman ruins, ancient torture chambers, and prisons, and in drawing after drawing pictured macabre sites." 4 Hobbs enumerates the anarchitectural structures that make up the landscape Smithson draws:

The elements that appear to have most intrigued him are an island, a circular hill surmounted by a winding staircase, and sharpened beams. In the drawing Entropic Landscape all of these are found, as well as another island supporting a layered burning pyre. ${ }^{5}$

He shows how the drawing is itself a collection of elements that are part of various other Earthworks designed or constructed by Smithson. It is not surprising that Hobbs sees macabre and baroque elements in Smithson's work. After all, Owens used Smithson's reliance on entropy to establish part of his definition of postmodern allegory. It is a theory of allegory based on Walter Benjamin's own elaboration on the $17^{\text {th }}$ century German mourning play, which he turned into a 
pivotal concept for materialist aesthetics. Owens' allegorical reading of Smithson through the inevitable decay brought about by entropy brings a melancholy air to the artist's enterprise.

By extension, geological landscapes seem to be expressive of something gloomy: the anticipated melancholia of an inevitably deserted planetary crust devoid of humans. It is, after all, a self-important humanism that Smithson is countering with his works, a humanism that Deleuze also wants to avoid. Entropy stands against the human and strips art of anthropocentrism. Whereas Smithson shows the devastating forces of entropy, Deleuze shows the fact of existence by analogizing thought to geological matter.

\section{Deleuze and Stratification}

For Deleuze, sedimentation of the mind has a very specific function in his philosophy. It denotes the material model of his virtual/actual duality. The virtual state is full of potentiality but is not perceived by us. Yet, it is nevertheless real since we are here, in an actual state-the formalization, as it were, of virtual potentiality. ${ }^{6}$ The virtual and the actual are the double facets of immanence, which is life in its totality.

The human mind is bound to the earth since the mind and the earth are part of the same environment. ${ }^{7}$ But if the earth is slow, the mind is fast. It is a question of speed. ${ }^{8}$ In $A$ Thousand Plateaus, Deleuze writes with Félix Guattari:

For there simultaneously occurs upon the earth a very important, inevitable phenomenon that is beneficial in many respects and unfortunate in many others: stratification. Strata are Layers, Belts. They consist of giving form to matters, of imprisoning intensities or locking singularities into systems of resonance and redundancy, of producing upon the body of the earth molecules large and small and organizing them into molar aggregates. ${ }^{9}$

The virtual and the actual are like two layers of strata. What separates them, the plane of consistency in Deleuze's model, is thought, which can have knowledge of both but separates them so they do not meet: “'A surface of stratification is a more compact plane of consistency lying between two layers.' The layers are the strata. They come at least in pairs, one serving as substratum for the other". ${ }^{10}$ For Deleuze, the virtual is the first articulation, the sedimentation. The actual is when sedimentation takes on a stable structure, a definitive form. He gives a geological example to illustrate this duality:

In a geological stratum, for example, the first articulation is the process of 'sedimentation,' which deposits units of cyclic sediment according to statistical order: flysch, with its succession 
of sandstone and schist. The second articulation is the 'folding' that sets up a stable functional structure and affects the passage from sediment to sedimentary rock. ${ }^{11}$

The geological processes are large scale mechanisms that take millions of years to come about but essentially function in the same way as does thought at infinite speeds.

Following the aesthetics of Smithson's project sketches, Deleuze's sedimentation would best be illustrated by Floating Island to Travel Around Manhattan Island, 1970. The sketch was real but the art project virtual: it was a project drawn with graphite on paper, until recently when it was actually realized (the plan made material). In 2005, Minetta Brook in collaboration with the Whitney Museum of American Art commissioned a tugboat to pull a barge with a landscape made of trees, dirt and rocks around Manhattan. This gesture of actualizing a 35-year-old plan certainly breaks with any kind of morose aesthetic associated with entropy and the baroque. Smithson's notion of entropy locates the work of art in the interstices between the material actuality of art and its virtual potential. Smithson's landscape is thus conceptual in its dynamic materiality.

\section{Kant and Cartography}

If infinite geological vistas devoid of humans are not morose for Deleuze, Kant is. Deleuze saw Kant as a worthy opponent, an enemy of sorts, or as a meteorological phenomenon when he called him the "fog from the north." In a lecture on Kant, Deleuze states:

It's an excessive atmosphere, but if one holds up, and the important thing above all is not to understand, the important thing is to take on the rhythm of a given man, a given writer, a given philosopher, if one holds up, all this northern fog which lands on top of us starts to dissipate, and underneath there is an amazing architecture. ${ }^{12}$

Kant spent forty years teaching a geography course. In fact, the only class he taught more often than this was his logic and metaphysics class. ${ }^{13}$ It is noteworthy that he was the first philosopher to introduce geography as a subject of study within the university. ${ }^{14}$ It is no wonder geography features in his philosophical work so prominently. In The Critique of Pure Reason, Kant represents his architectonic through geographical metaphors. This is a significant point with several consequences which exceed the duality of metaphorical register in a philosophical discourse. In trying to give the philosophy its image, these geographical representations are instrumental in the self-reflexive process of the philosophical system. This spatial articulation in turn lends credibility to a material dimension of the system. It does so because of the particular ontological depth contained 
in geography for Kant. Geography has a particular function in thought. The activity of using geography to reflect on the philosophical system is perpetrated from the vantage point of the system's boundary. To reflect on the system, one must be part of it (like Smithson's figure of the artist in the midst of a geological landscape), but enough on the sidelines to see it from the broadest angle, in a similar way as one stands against a wall to see most of the room. This is why a passage in The Critique of Pure Reason which displays such geographical and spatial imagination must be highlighted:

We have now not only traveled through the land of pure understanding, and carefully inspected each part of it, but we have also surveyed it, and determined the place for each thing in it. This land, however, is an island, and enclosed in unalterable boundaries by nature itself. It is the land of truth (a charming name), surrounded by a broad and stormy ocean, the true seat of illusion, where many a fog bank and rapidly melting iceberg pretend to be new lands and, ceaselessly deceiving with empty hopes the voyager looking around for new discoveries, entwine him in adventures from which he can never escape and yet also never bring to an end. ${ }^{15}$

These geographical images as a way of reflecting on the architectonic are not simple metaphors of a philosophical system; rather they are part of the constitution of a critical system. ${ }^{16}$ Similarly, Deleuze notes the importance of the subjective mind, the critical mind, in the geographic model of his own philosophy by saying that " $[\mathrm{t}]$ he plane is surrounded by illusions" but we have a role to play in dissipating these illusions that rise "like vapours from a pond" and therefore we must acknowledge the limit of the system in order to critique it since "it is we ourselves who approach the plane of immanence, who are on the absolute horizon". ${ }^{17}$ The image of thought we create for ourselves is both inside and out, part of our metaphorical imagination and material space.

Coming back to Kant's critical geography, Richard Hartshorne shows how in the $18^{\text {th }}$ century, theories were developed for the purpose of inserting the human being into a system of nature. If we are reminded of Smithson's artist-figure being inserted into the mind's landscape, in the present context, however, humans are made a part of the geographical setting-we are part of the landscape: “...the individual lands and districts were 'organisms' which like any organism included a physical

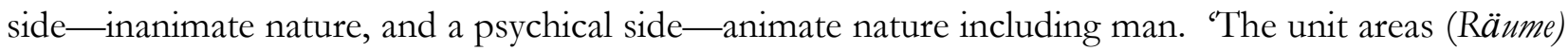
assimilate their inhabitants' and 'the inhabitants strive no less constantly to assimilate their areas.",18 So a human, social model is added to the geographical model. This juxtaposition creates an environment to which the critical subject is intrinsically linked. Kant's model can be seen from the point of view of Smithson's concern with the body as mediation between thought and the earth. 
Geography is then an organism, with the human being as a vital component of its organizational structure. The notion that the inhabitant is dependent on nature and the surrounding environment is inescapable for Kant: "Thus Kant not only included man as one of the features, 'encompassed in the earth surface (Erboden)', but also considered man as one of the five principal agents affecting changes on the earth..."19 The space the inhabitants occupy on the physical ground, insofar as they are part of the system of nature, indicates the importance of the spatial location of the human being as part of existence and, by extension, as a ground for politics. The political concept of cosmopolitanism reflects society or the social functions teleologically, enfolded within the overall system of nature: 'Yet it may be assumed that nature does not work without a plan and purposeful end, even amidst the arbitrary play of human freedom, this idea might nevertheless prove useful". ${ }^{20}$ On a larger scale, however, a systematic organization is crucial to the understanding of this view of the world. Nature, in its systematicity, provides a model for the organization of thought. Cosmopolitanism is a product of such a systematic organization of the world: "And although we are too short-sighted to perceive the hidden mechanism of nature's scheme, Kant writes, this idea may yet serve as a guide to us in representing an otherwise planless aggregate of human actions as

conforming, at least when considered as a whole, to a system". 21 The scale of organization of human action is not determined by a history, but by the spatial arrangement of nature's system. It is on a spatial plane that humans can be critical.

The landscape communicates organizational structures by analogies established at different scales - from the landscape of the mind, to an environmental organism, to social and political strata. The landscape is then not simply a representation but an active matrix.

\section{Ewen's Diagram}

Kant's empirical and critical uses of geography are best applied to Ewen's art because it is at the crux of scientific and artistic depictions of geographical events. Ewen's works depict natural phenomena such as weather system formation, natural occurrences on a planetary scale and geological structures such as artesian wells. His technique involves the body's physicality (his own), mediated by machinery (the router), which digs into plywood and, by accepting the accidents of the wood patterns, brings the materiality of the work to the fore. But a very important element in Ewen's style is the diagrammatic depiction of usually unseen forces: "The elementary quality of this gesture resembled a reductive, scientific diagram and at the same time embodied the active transfer of energy 
through $\mathrm{h}$ indeterminate space." 22 This diagrammatic gesture provides an interface for the body, materiality and the mind.

The origin of Ewen's interest in earthly phenomena as a subject matter of his oeuvre is attributed to his interest in geology. Ewen explains: "I thought all during my boyhood that I wanted to be a geologist until I took my first course and found that geologists are not so interested in the shapes and colours of formations but in their specific density and other mathematical and scientific data." ${ }^{23}$ The reduction of earthly phenomena to mathematical formulae persisted and Ewen finally developed a style that incorporated the industrial to the artistic material to give justice to the violent and enormous phenomena he was depicting. Rocks Moving in the Current of a Stream, 1971 brings together all of these elements: not only does the material consist of galvanized steel (to give an impression of water), wood and linoleum, the subject matter is a diagram of a geological occurrence organized to: "strongly sugges[t] 'an imagery that touched on the sciences,' leading him to submit to what he calls his disease for old illustrated dictionaries and encyclopedia and laymen's books on the physical sciences in the search for subject matter." 24 Rocks Moving in the Current of a Stream consists of two metal panels that form a rectangular surface divided by a seam. This seam organizes the space of the work's surface. On the bottom half, on the lower edge of the piece, four rocks are shown to be moving through rotation from left to right. Their movement and directionality are indicated by black arrows, curved or straight near the rocks. Above this line, near the top edge of the lower metal panel, three smaller stones are shown, again with the help of broken arrows emanating from the larger rocks, holding the small stone at their acme and pointing downwards again, to bounce from the large rocks that roll at the bottom of the river. The small arrows toggling the large rocks indicate a slow pace; the long, high-arched arrows indicate a higher speed and longer distance covered. Finally, on the top panel which is equal in height to the bottom one, small dots represent pebbles swiftly swimming with the current. Only one arrow succinctly shows the speed of their travels. At the outer edge, a wavy pattern indicates where the river's surface caps off the underwater view.

This schema, depicted with very rough material, provides the tension between the materiality of the work of art and the organization of materials of nature which in turn are analogized in the way our mind works.

\section{DeLanda and the Environment as Organization}

If Deleuze analogizes the mind to geological formation and Kant places the subject on the material terrain of geography to have a strong theoretical ground to stand on, it is Smithson, with his 
aesthetic depiction of thought processes in terms of the geological function, who might be closer to critical exactitude. That is because by putting the mind and the earth on the same terrain, he brings out what makes them part of the same matter: their function.

DeLanda shows how the analogical function of such systematic models, spanning from geology to society, works. It is important to note that the function that ties these models together is also geological in nature.

DeLanda gives us a more complete picture of this function. In "Deleuze, Diagrams, and the Genesis of Form," DeLanda shows why Deleuze is so interested in geological systems; their organizational functions are the same as in other aspects of life: genetics and society and by extension, the mind.

DeLanda provides two different models of organization that will stand in for function: the sedimentary and the meshwork. What he demonstrates in his enumeration of sedimentary organization in geology, genetics and society versus meshwork organization in the same domains, is an analogy erased in favour of function. These instances of geological sedimentation, genetic evolution and social stratification are not just like one another. Rather, the function of sedimentation is the same as the function of evolution and social stratification

This functional arc between geology, genetics and society is drawn and cemented by the presence of another diagram supporting its actual trajectory: the meshwork diagram. But the mechanism of sedimentation in geology is the mechanism of sedimentation in genetics. It is the same object that is present in a different place. As architectural theorist Sanford Kwinter explains, there are incorporeal, non-spatial manifestations: "Now integration, organization, and coordination are each abstract nouns without demonstrable correlates in the physical or chemical world. Yet this does not mean that they are immaterial -far from it! -only that they are incorporeal'. ${ }^{25}$ 'This incorporeal mechanism can be translated onto Deleuze's own system: sedimentation would be filtering. Meshwork would be the environment.

The three models of strata follow a horizontal pattern: 1. geological: a) pebbles of different sizes are sorted, that is, filtered, by the current of the river. They are guided by the flow of the river and when they arrive at the bottom of the waterbed, the small pebbles fall together, as do bigger ones; b) after the process of sedimentation, both small and big pebbles are cemented together where they fell: "certain substances dissolved in water which penetrate the sediment through the gaps between pebbles." 26 2. evolutionary: a) the sorting process in genes occurs over time according to selection, survival, climate, geography and parasites; b) this process is cemented when a gene pool is 
closed off: a species emerges that cannot reproduce with others. 3. social: a) members of a society are sorted according to different mechanisms which hierarchize the social spheres; b) these relations are cemented by a codification of the network. Each of these different spheres of reality-geological, evolutionary and social-are analogous, but the process at work is the same: ontologically different in formal reality but still real in its function. The three elements are allagmatically put in relation with one another, they actually are, and are not just representations of, each other.

The previous three models will now be surveyed in a vertical direction. The three models of the meshwork network in DeLanda's scheme are: 1. geological: volcanic eruptions give rise to "a complex of heterogeneous crystals which interlock with one another" in igneous rocks through the process of the magma cooling down instead of the double process of sorting and cementing. 2 . evolutionary: the meshwork network in this case is the example of the eco-system. Food and energy are complementary to prey-predator and parasite-host relations which, in turn, depend on vegetation, digestion and microorganisms at work. 3. social: money and the marketplace are a way of immediately relating individuals and collapsing time and distance, which the sorting mechanism of codification put in place through hierarchizing and cementing.

These two organizational models, of sedimentary and meshwork, are complementary but their function is what brings them to a single actual level that springs from a single actual level of virtuality. The process is the diagram that constrains multiplicities, sorting and cementing while at the same time putting them all in a far-from-equilibrium state of meshwork networks.

What is interesting in the whole idea of diagrammatic process can be witnessed at the level of the example that DeLanda provides in order to define the process. In order to explain what a stratum is DeLanda has to explain how a stratum functions. A stratum is, by definition, how it functions. This definition of the strata (rocks, water, etc.) coincides with Deleuze's concept. The concept of the strata and an actual, physical stratum do have something in common. But it is not the representation of one term (the physical strata) by the other (the conceptual strata). Rather, it is actually the function that makes them not just similar, but actually the same. They are the same because of the way that these explanations are based on the argument that reality-what is actual-is constructed by the abstract machine, that is, it is based on functions: the analogy between the real object and its philosophical concept slides seamlessly. Behind the fabric of reality, behind the actual, there is a multiplicity of processes from which spontaneous forms emerge like volcanic islands on the tumultuous sea. What takes place at this level of virtuality is based on the constraint of the diagrammatic function, the abstract machine - the purview of artists such as Smithson and Ewen. 
The function of these strata is simply covered by the fog of formalism which dissipates when looked at through the lens of materiality: Kant through his critique, and Deleuze through the focus on abstract machines, i.e. the function thought. These in turn are illustrated by Smithson. Or if we follow the philosopher's guidelines, made actual and real as any rocky mass.

Smithson's drawn landscapes showcase entropy as the mechanism behind matter binding objects to the earth. Read through his texts on the sedimentary nature of thought; these landscapes offer a glimpse into the mind's landscape. Ewen's galvanized steel painting of the organization of rocks in the river, when read through DeLanda's models of systems, is an illustration of the artist's mission to diagrammatically represent a landscape that rarely features in painting but that nevertheless illustrates material forces tying us to our environment through a material analogy. It is no wonder that Deleuze and Kant both chose geological and geographic textual representations to communicate their image of thought. According to these artists and philosophers, the landscape is an important way of figuring out our mind and how it fits into our surrounding environment.

\section{Notes}

${ }^{1}$ Craig Owens. The Allegorical Impulse: Toward a Theory of Postmodernism. October, Vol. 12 (Spring, 1980$), 72$.

2 Smithson, Robert. A Sedimentation of the Mind: Earth Projects (1968). Robert Smithson: The Collected Writings. Ed. Jack Flam (Berkeley: U of California P., 1996), 100.

${ }^{3}$ Ibid.

${ }^{4}$ Robert Hobbs. Robert Smithson: Sculpture. (Ithaca: Cornell, UP, 1981), 210.

${ }^{5}$ Ibid.

${ }^{6}$ Gilles Deleuze. Proust and Signs. Trans. Richard Howard. (New York: George Braziller, 1972), 60.

${ }^{7}$ Gilles Deleuze and Félix Guattari, What is Philosophy?, trans. Hugh Tomlinson and Graham Burchell (New York:

Columbia University Press, 1994), 36-37.

${ }^{8}$ Ibid., 41.

${ }^{9}$ Gilles Deleuze and Félix Guattari. A Thousand Plateaus: Capitalism and Schizophrenia. Trans. Brian Massumi. (Minneapolis: U of Minnesota P, 2005), 40.

10 Ibid.

11 Ibid., 41.

12 Gilles Deleuze. Lecture on Kant: time and synthesis of 14/04/1978:

http:/ /www.webdeleuze.com/php/texte.php?cle=66\&groupe=Kant\&langue=2

13 Immanuel Kant. Géographie (Physische Geographie). Trans. Michèle Cohen-Halimi, Max Marcuzzi and Valérie Seroussi. (Paris: Aubier. 1999), 11.

14 Ibid.

${ }^{15}$ Kant, Immanuel. The Critique of Pure Reason. Trans. and ed. Paul Guyer, Allen W. Wood. (Cambridge: Cambridge UP, 1998), A 235-36 \B 294-95. Author's bold. 


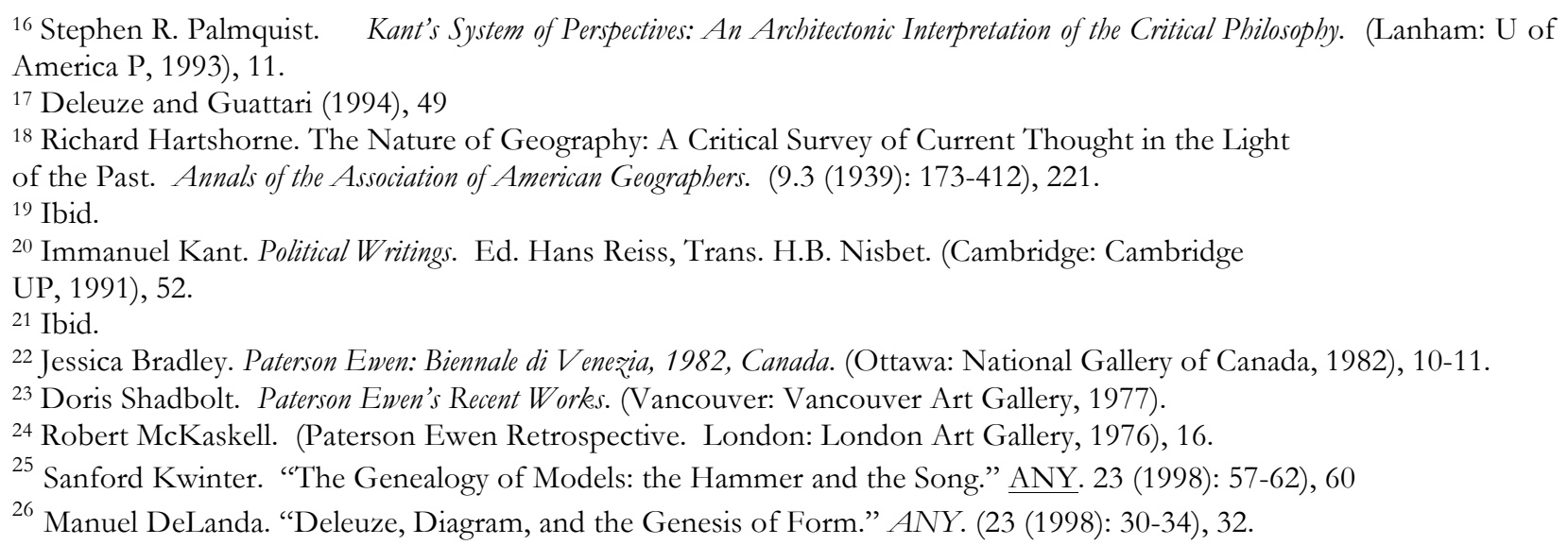

\section{Bibliography}

Bradley, Jessica. Paterson Ewen: Biennale di Venezia, 1982, Canada. Ottawa: National Gallery of Canada, 1982).

Deleuze, Gilles. Les cours de Gilles Deleuze: Deleuze/Kant. Cours Vincennes 04/04/1978.http://www.webdeleuze.com/php/texte.php?cle=65\&groupe=Kant\&langue $=2$ . Proust and Signs. Translated by Richard Howard. New York: George Braziller, 1972.

Deleuze, Gilles; Guattari, Félix. A Thousand Plateaus: Capitalism and Schizophrenia. Translated by Brian Massumi. Minneapolis: University of Minnesota Press 2005 . What is Philosophy? Translated by Hugh Tomlinson and Graham Burchell. New York: Columbia University Press, 1994.

DeLanda, Manuel. "Deleuze, Diagram, and the Genesis of Form." ANY. 23 (1998): 30-34.

Hartshorne, Richard. "The Nature of Geography: A Critical Survey of Current Thought in the Light of the Past." Annals of the Association of American Geographers. 29.3 (1939): 173-412.

Hobbs, Robert. Robert Smithson: Sculpture. Ithaca: Cornell, University Press, 1981.

Kant, Immanuel. The Critique of Pure Reason. Translated and edited by Paul Guyer, Allen W. Wood. Cambridge: Cambridge University Press, 1998. . Géographie (Physische Geographie). Translated by Michèle Cohen-Halimi, Max Marcuzzi and Valérie Seroussi. Paris: Aubier. 1999. . Political Writings. Edited by Hans Reiss. Translated by H.B. Nisbet. Cambridge: Cambridge University Press, 1991.

Kwinter, Sanford. "The Genealogy of Models: the Hammer and the Song." ANY. 23 (1998): 57-62.

McKaskell, Robert. Paterson Ewen Retrospective. London: London Art Gallery, 1976.

Owens, Craig. "The Allegorical Impulse: Toward a Theory of Postmodernism.” October 12 (Spring, 1980): 67-88.

Palmquist, Stephen R. Kant's System of Perspectives: An Architectonic Interpretation of the Critical Philosophy. Lanham: Univeristy of America Press, 1993. 
Shadbolt, Doris. Paterson Ewen's Recent Works. Vancouver: Vancouver Art Gallery, 1977.

Smithson, Robert. "A Sedimentation of the Mind: Earth Projects." In Robert Smithson:

The Collected Writings, edited by Jack Flam, 100-13. Berkeley: University of California Press, 1996. 